\title{
Paracoccus saliphilus sp. nov., a halophilic bacterium isolated from a saline soil
}

\author{
Yun Wang, ${ }^{1} \dagger$ Shu-Kun Tang, ${ }^{2} \dagger$ Kai Lou, ${ }^{1}$ Pei-Hong Mao, ${ }^{3}$ Xiang Jin, ${ }^{3}$ \\ Cheng-Lin Jiang, ${ }^{2} \mathrm{Li}-\mathrm{Hua} \mathrm{Xu}^{2}$ and Wen-Jun $\mathrm{Li}^{2}$ \\ ${ }^{1}$ Xinjiang Institute of Microbiology, Xinjiang Academy of Agricultural Science, Urumqi, Xinjiang \\ 830091, PR China \\ ${ }^{2}$ The Key Laboratory for Microbial Resources of the Ministry of Education, PR China, and \\ Laboratory for Conservation and Utilization of Bio-Resources, Yunnan Institute of Microbiology, \\ Yunnan University, Kunming 650091, PR China \\ ${ }^{3}$ Institute of Ion Beam Biotechnology, College of Physics Science and Technology, Xinjiang \\ University, Urumqi, Xinjiang 830008, PR China
}

Correspondence

Wen-Jun Li

wjli@ynu.edu.cn or

liact@hotmail.com
The genus Paracoccus Davis 1969 was proposed by Davis et al. (1969). At the time of writing, the genus comprised 26 recognized species. Owing to the physiological versatility of members of the genus, the description of the genus Paracoccus has been emended several times (Ludwig et al., 1993; Katayama et al., 1995; Liu et al., 2008). The most recently described species at the time of writing are Paracoccus halophilus (Liu et al., 2008) and Paracoccus marinus (Khan et al., 2008). Species of the genus are characterized as Gram-negative and catalase- and oxidasepositive, with high metabolic versatility, being halophilic or halotolerant, having a large amount of $\mathrm{C}_{18: 1} \omega 7 c$ and having ubiquinone 10 as the major isoprenoid quinone. A moderately halophilic bacterium, designated strain YIM $90738^{\mathrm{T}}$, was isolated from a saline soil sample and is shown here to represent a novel species of the genus Paracoccus.

Strain YIM $90738^{\mathrm{T}}$ was isolated from a saline soil sample taken from the edge of the Ebinur Lake wetland natural

†These authors contributed equally to this work.

The GenBank/EMBL/DDBJ accession number for the $16 \mathrm{~S}$ rRNA gene sequence of strain YIM $90738^{\top}$ is DQ923133. reserve, which is located in the arid area of north-west Xinjiang province, north-west China; the wetland forms the lowest part of the west Junggar Basin. The sampling site is at $44^{\circ} 34^{\prime} 07^{\prime \prime} \mathrm{N} 83^{\circ} 44^{\prime} 25^{\prime \prime}$ E. The major ion components of the soil $\left(\mathrm{g} \mathrm{l}^{-1}\right)$ were $\mathrm{Na}^{+}(35.00), \mathrm{K}^{+}$ (0.48 g), $\mathrm{Ca}^{2+}$ (0.38), $\mathrm{Mg}^{2+}$ (4.73), $\mathrm{Cl}^{-}$(38.01), $\mathrm{SO}_{4}^{2-}$ (40.34) and $\mathrm{HCO}_{3}^{-}(0.32)$. Strain YIM $90738^{\mathrm{T}}$ was isolated on modified ISP 5 medium by using the routine dilution plating method; the medium contained (per litre distilled water) $1 \mathrm{~g}$ L-asparagine, $10 \mathrm{~g}$ glycerol, $5 \mathrm{~g}$ yeast extract, $1 \mathrm{~g}$ $\mathrm{K}_{2} \mathrm{HPO}_{4}, 5 \mathrm{~g} \mathrm{KNO}_{3}, 100 \mathrm{~g} \mathrm{NaCl}$ and $15 \mathrm{~g}$ agar. The medium was adjusted to $\mathrm{pH}$ 7.5. Colonies were picked and repeatedly restreaked onto modified ISP 5 medium until purity was confirmed.

Strain YIM $90738^{\mathrm{T}}$ was cultivated on modified ISP 5 medium at $37{ }^{\circ} \mathrm{C}$ for investigation of morphological and physiological characteristics. The strain was maintained on modified ISP 5 agar slants containing $8 \% \mathrm{NaCl}(\mathrm{w} / \mathrm{v})$ at $4{ }^{\circ} \mathrm{C}$ and as $20 \%$ (w/v) glycerol suspensions at $-20{ }^{\circ} \mathrm{C}$. Cell biomass of strain YIM $90738^{\mathrm{T}}$ for respiratory isoprenoid quinone analysis and for extraction of DNA was obtained by cultivation in shaken flasks (about 
150 r.p.m.) by using modified ISP 5 broth at $37^{\circ} \mathrm{C}$ for about 1 week. For fatty acid methyl ester analysis, cell mass of strain YIM $90738^{\mathrm{T}}$ was obtained from agar plates after incubation for 2 days on trypticase soy agar (TSA; Difco) containing $8 \% \mathrm{NaCl}$ at $37{ }^{\circ} \mathrm{C}$.

Gram staining was carried out by the standard Gram reaction and was confirmed by using the $\mathrm{KOH}$ lysis test method (Cerny, 1978). Cell motility was confirmed by the presence of turbidity throughout a tube containing semisolid medium (Leifson, 1960). Cell morphology was observed by light microscopy (model $\mathrm{BH} 2$; Olympus) and transmission electron microscopy (model H-800; Hitachi) by using cells from exponentially growing cultures. Colony morphology was observed on modified ISP 5 medium after incubation at $37^{\circ} \mathrm{C}$ for 5 days. The methyl red and Voges-Proskauer tests were investigated as described by Lányí (1987). The temperature range for growth was determined by incubating cells for 1 week on modified ISP 5 medium at 4, 10, 15, 20, 28, 37, 45, 55 and $65{ }^{\circ} \mathrm{C}$. The $\mathrm{pH}$ growth range was investigated between $\mathrm{pH} 4.0$ and 10.0 at intervals of $1 \mathrm{pH}$ unit, by using the buffer system described by Xu et al. (2005). Liquid cultures were incubated on a rotary shaker at $37{ }^{\circ} \mathrm{C}$ for $2-3$ weeks using modified ISP 5 as the basal medium. Tolerance to chlorides of sodium, potassium and magnesium was tested by using the same basal medium, with concentrations of the above at $0,1,3,5,8,10,12,15,18,20,25$ and $30 \%$ $(\mathrm{w} / \mathrm{v})$. Catalase activity was determined by production of bubbles after the addition of a drop of $3 \% \mathrm{H}_{2} \mathrm{O}_{2}$. Oxidase activity was observed by oxidation of tetramethyl- $p$ phenylenediamine. Hydrolysis of casein, starch, CMcellulose, gelatin, pectin, tyrosine and Tweens 20,40 and 80 was determined as described by Cowan \& Steel (1965). Metabolic properties and enzyme activities were determined by means of the API 20NE and API ZYM systems (bioMérieux) according to the manufacturer's instructions. Utilization of organic substrates was tested by using Biolog GN2 microplates. Cell suspensions were prepared by using pre-warmed sterile saline solution $(8 \% \mathrm{NaCl}, \mathrm{w} / \mathrm{v})$, within the density range specified by the manufacturer. The detailed physiological and biochemical properties of strain YIM $90738^{\mathrm{T}}$ are given in Table 1 and in the species description.

Fatty acids were analysed as described by Sasser (1990) by using the Microbial Identification System (MIDI). Isoprenoid quinones were extracted and purified as described by Komagata \& Suzuki (1987). The purified ubiquinones were dissolved in acetone and separated by reversed-phase HPLC.

Extraction of genomic DNA and PCR amplification of the $16 \mathrm{~S}$ rRNA gene were done as described by Li et al. (2007). The genomic DNA G $+\mathrm{C}$ content was determined by reversed-phase HPLC (Mesbah et al., 1989). The sequence obtained for strain YIM $90738^{\mathrm{T}}$ was compared with other publicly available 16S rRNA gene sequences deposited in the GenBank/DDBJ/EMBL databases. The multiple sequence alignment program CLUSTAL X (Thompson et al., 1997) was used to align the 16S rRNA gene sequences of the new isolate and representative members of selected genera. Phylogenetic analyses were performed by using the neighbour-joining (Saitou \& Nei, 1987), maximumlikelihood (Felsenstein, 1981) and maximum-parsimony (Fitch, 1971) methods. A phylogenetic tree was constructed according to the neighbour-joining method of Saitou \& Nei (1987) from $K_{\text {nuc }}$ values (Kimura, 1980) by using MEGA version 3.0 (Kumar et al., 2004). The topology of the phylogenetic tree was evaluated by bootstrap resampling based on 1000 replicates (Felsenstein, 1985). DNA-DNA hybridization studies were performed according to the method of Ezaki et al. (1989), by using photobiotinlabelled DNA probes and microdilution wells. Paracoccus homiensis DSM $17862^{\mathrm{T}}$ was used as a reference strain for DNA-DNA hybridizations. DNA-DNA hybridization experiments were performed in triplicate. The hybridization temperature was $42{ }^{\circ} \mathrm{C}$, which is within the limit of validity for the filter method (De Ley \& Tijtgat, 1970).

Cells of strain YIM $90738^{\mathrm{T}}$ were Gram-negative, non-motile, cocci to short rods, $1.6-2.0 \times 2.5-5.5 \mu \mathrm{m}$; no spores were observed. Optimum growth occurred at $\mathrm{pH} 7.0$ and $37{ }^{\circ} \mathrm{C}$ on modified ISP 5 medium. At $37^{\circ} \mathrm{C}$, strain YIM $90738^{\mathrm{T}}$ grew at total salt concentrations of $1-15 \%(w / v)$. Strain YIM $90738^{\mathrm{T}}$ did not grow in the absence of $\mathrm{NaCl}$; optimal growth was at $8 \% \mathrm{NaCl}$, which indicated that the isolate could be assigned to the group of moderately halophilic bacteria (Kushner \& Kamekura, 1988). Strain YIM $90738^{\mathrm{T}}$ was unable to grow in the presence of only $\mathrm{KCl}$ or $\mathrm{MgCl}_{2} \cdot 6 \mathrm{H}_{2} \mathrm{O}$ on modified ISP 5 medium. Table 1 provides a comparison of the phenotypic characteristics of strain YIM $90738^{\mathrm{T}}$ and closely related species of the genus Paracoccus.

Strain YIM $90738^{\mathrm{T}}$ contained ubiquinone Q-10 as the predominant isoprenoid quinone. The major cellular fatty acid was $\mathrm{C}_{18: 1} \omega 7 c\left(80.4 \%\right.$ of the total); $\mathrm{C}_{18: 0}(6.1 \%)$, $\mathrm{C}_{10: 0} 3-\mathrm{OH}(3.3 \%)$ and $\mathrm{C}_{19: 0}$ cyclo $\omega 8 c(2.6 \%)$ were detected as minor components. This fatty acid profile (Table 2) and ubiquinone Q-10 as the predominant isoprenoid quinone were consistent with data for recognized members of the genus Paracoccus (Kim et al., 2006). The DNA G + C content of strain YIM $90738^{\mathrm{T}}$ was $60.3 \mathrm{~mol} \%$, lower than that of some species of the genus Paracoccus (Table 1), but similar to that of Paracoccus sulfuroxidans (61.3 mol\%; Liu et al., 2006) and Paracoccus kondratievae (62.5 mol\%; Doronina et al., 2002).

An almost-complete 16S rRNA gene sequence (1389 bp) was determined for strain YIM $90738^{\mathrm{T}}$ and was used for BLAST searches and phylogenetic analysis. Sequence alignment showed that strain YIM $90738^{\mathrm{T}}$ had highest $16 \mathrm{~S}$ rRNA sequence similarity to members of the genus Paracoccus. Phylogenetic analysis was based on sequences of representative strains of the genus Paracoccus, and the type strain of Rhodobacter capsulatus was used as the outgroup. In the phylogenetic tree based on the neighbourjoining algorithm, strain YIM $90738^{\mathrm{T}}$ shared the same 
Table 1. Differential characteristics between strain YIM $90738^{\top}$ and the type strains of related species of the genus Paracoccus

Strains: 1, YIM 90738 ${ }^{\mathrm{T}}$; 2, P. homiensis DSM $17862^{\mathrm{T}}$ (data from Kim et al., 2006); 3, P. zeaxanthinifaciens ATCC 21588 ${ }^{\mathrm{T}}$ (Berry et al., 2003); 4 , P. carotinifaciens IFO $16121^{\mathrm{T}}$ (Tsubokura et al., 1999); 5, P. haeundaensis KCCM 10460 ${ }^{\mathrm{T}}$ (Lee et al., 2004); 6, P. marcusii DSM $11574^{\mathrm{T}}$ (Harker et al., 1998); 7, P. seriniphilus DSM $14827^{\mathrm{T}}$ (Pukall et al., 2003). ND, No data available.

\begin{tabular}{|c|c|c|c|c|c|c|c|}
\hline Characteristic & 1 & 2 & 3 & 4 & 5 & 6 & 7 \\
\hline Cell morphology ${ }^{*}$ & $\mathrm{C}-\mathrm{SR}$ & $\mathrm{R}-\mathrm{O}$ & $\mathrm{C}-\mathrm{SR}$ & $\mathrm{R}$ & $\mathrm{R}$ & $\mathrm{C}-\mathrm{SR}$ & $\mathrm{C}-\mathrm{R}$ \\
\hline Pigmentation $\dagger$ & $\mathrm{NP}-\mathrm{YB}$ & $\mathrm{NP}-\mathrm{CW}$ & $\mathrm{Y}-\mathrm{OR}$ & $\mathrm{OR}-\mathrm{RD}$ & $\mathrm{OR}-\mathrm{RD}$ & OR & $\mathrm{NP}-\mathrm{CW}$ \\
\hline Flagellation & - & + & - & + & - & - & - \\
\hline Motility & - & + & - & + & - & - & - \\
\hline Growth at $55{ }^{\circ} \mathrm{C}$ & + & - & - & - & - & - & - \\
\hline Growth at $15 \%(w / v) ~ N a C l$ & + & + & - & - & - & - & - \\
\hline $\mathrm{pH}$ range & $6.0-8.0$ & $5.0-9.0$ & $6.1-9.1$ & ND & $6.0-10.5$ & ND & $5.0-10.0$ \\
\hline Nitrate reduction & - & - & - & - & + & - & + \\
\hline \multicolumn{8}{|l|}{ Growth on: } \\
\hline Acetic acid & + & + & - & ND & ND & - & + \\
\hline Adonitol & + & - & - & + & - & + & + \\
\hline L-Aspartate & + & + & + & + & ND & - & + \\
\hline L-Asparagine & + & - & + & + & - & - & + \\
\hline i-Erythritol & - & + & - & + & ND & + & + \\
\hline Gentiobiose & + & - & - & + & ND & + & - \\
\hline L-Phenylalanine & - & + & - & ND & ND & - & - \\
\hline Propionic acid & - & + & - & ND & ND & + & + \\
\hline Quinic acid & + & - & - & + & ND & + & - \\
\hline L-Rhamnose & - & + & - & ND & - & - & - \\
\hline D-Sorbitol & + & + & - & + & - & + & + \\
\hline Succinic acid & + & + & - & ND & ND & + & - \\
\hline Xylitol & + & - & - & + & ND & + & + \\
\hline DNA G $+\mathrm{C}$ content $(\mathrm{mol} \%)$ & 60.3 & 63.0 & $66.9-67.7 \ddagger$ & 67 & 66.9 & 66 & 63.3 \\
\hline
\end{tabular}

${ }^{*}$ C, Cocci; O, ovoid; R, rods; SR, short rods.

$\dagger \mathrm{NP}$, Colourless; CW, creamy white; OR, orange; RD, red; Y, yellow; YB, yellow-brown.

$\ddagger$ Range of values for five strains including the type strain.

branch as $P$. homiensis DD-R $11^{\mathrm{T}}$ and Paracoccus zeaxanthinifaciens R-1506 (Fig. 1) and showed the highest levels of $16 \mathrm{~S}$ rRNA gene sequence similarity to these strains ( 97.5 and $96.3 \%$, respectively); levels of similarity to the type strains of other recognized species of the genus Paracoccus were less than $96.3 \%$. The topologies of phylogenetic trees built with the maximum-likelihood and maximum-parsimony algorithms were similar to that of the neighbourjoining tree (data not shown).

Based on DNA-DNA hybridizations, strain YIM $90738^{\mathrm{T}}$ showed a level of DNA-DNA relatedness of $51.5 \pm 4 \%$ (mean $\pm \mathrm{SD}$ of three determinations) to $P$. homiensis DSM $17862^{\mathrm{T}}$. This, combined with levels of $16 \mathrm{~S}$ rRNA gene sequence similarity, supports the genomic distinction of strain YIM $90738^{\mathrm{T}}$ from recognized species of the genus Paracoccus (Stackebrandt \& Goebel, 1994; Wayne et al., 1987). Strain YIM $90738^{\mathrm{T}}$ could also be differentiated from recognized Paracoccus species based on differences in several phenotypic characteristics. Therefore, on the basis of the data presented, strain YIM $90738^{\mathrm{T}}$ is considered to represent a novel species of the genus Paracoccus, for which we propose the name Paracoccus saliphilus sp. nov.

\section{Description of Paracoccus saliphilus sp. nov.}

Paracoccus saliphilus (sa.li.phi'lus. L. n. sal, salis salt; Gr. adj. philos loving; N.L. masc. adj. saliphilus salt-loving).

Cells are aerobic, Gram-negative, non-spore-forming, nonmotile, coccoid to rod-shaped, 1.6-2.0 $\times 2.5-5.5 \mu \mathrm{m}$. Colonies are circular, smooth, flat and colourless to yellow-brown. Moderately halophilic; grows over a wide range $(1-15 \%, \mathrm{w} / \mathrm{v})$ of salt concentrations, with optimal growth at $8 \%(w / v) ~ N a C l$. No growth in the absence of $\mathrm{NaCl}$. Growth occurs at $10-55^{\circ} \mathrm{C}$ and at $\mathrm{pH} 6.0-8.0$; optimal growth is at $37{ }^{\circ} \mathrm{C}$ and $\mathrm{pH}$ 7.0. Positive for oxidase, catalase and the Voges-Proskauer test. Indole and $\mathrm{H}_{2} \mathrm{~S}$ are not produced. Nitrate is not reduced. Negative for arginine dihydrolase, lysine decarboxylase, ornithine decarboxylase and methyl red. Gelatin, urea and aesculin are hydrolysed, but casein, starch, CM-cellulose, pectin, tyrosine and Tweens 20, 40 and 80 are not. Enzyme activities (tested in the API ZYM system) are observed for alkaline phosphatase, esterase (C4), esterase lipase (C8), leucine arylamidase, valine arylamidase, cystine arylamidase, trypsin, acid phosphatase, naphthol-AS-BI-phospho- 
Table 2. Comparison of the fatty acid profiles of strain YIM $90738^{\top}$ and its nearest phylogenetic neighbours within the genus Paracoccus

Strains: 1 , YIM $90738^{\mathrm{T}}$ (grown on TSA at $37^{\circ} \mathrm{C}, \mathrm{pH} 7.3$ and $8 \%$ $\mathrm{NaCl}$; data from the present study); 2, P. homiensis DSM $17862^{\mathrm{T}}$ (marine agar, $28{ }^{\circ} \mathrm{C}, \mathrm{pH}$ 7.0; Kim et al., 2006); 3, P. zeaxanthinifaciens ATCC $21588^{\mathrm{T}}$ (TSA, $28^{\circ} \mathrm{C}, \mathrm{pH}$ 7.3; Kim et al., 2006); 4, P. carotinifaciens IFO $16121^{\mathrm{T}}$ (TSA, $28{ }^{\circ} \mathrm{C}, \mathrm{pH}$ 7.3; Kim et al., 2006); 5, P. haeundaensis KCCM $10460^{\mathrm{T}}$ (TSA, $25^{\circ} \mathrm{C}, \mathrm{pH} 8.0$; Lee et al., 2004); 6, P. marcusii DSM $11574^{\mathrm{T}}$ (TSA, $28{ }^{\circ} \mathrm{C}, \mathrm{pH}$ 7.3; Kim et al., 2006); 7, P. seriniphilus DSM $14827^{\mathrm{T}}$ (TSA, $30{ }^{\circ} \mathrm{C}, \mathrm{pH}$ 7.3; Pukall et al., 2003). Values are percentages of total fatty acids. - , Not detected or $<1 \%$; NA, not applicable (listed as a component of a summed feature).

\begin{tabular}{|lccccccc|}
\hline Fatty acid & $\mathbf{1}$ & $\mathbf{2}$ & $\mathbf{3}$ & $\mathbf{4}$ & $\mathbf{5}$ & $\mathbf{6}$ & $\mathbf{7}$ \\
\hline $\mathrm{C}_{10: 0}$ 3-OH & 3.3 & 2.6 & 4.9 & 3.4 & 2.1 & 6.2 & 7.9 \\
Unidentified ECL & - & 2.4 & 3.6 & 2.8 & - & 4.9 & - \\
$\quad 11.799$ & & & & & & & \\
Unidentified ECL & - & - & 1.6 & 1.1 & - & 2.9 & - \\
15.275 & & & & & & & \\
$\mathrm{C}_{12: 1} \omega 7 c$ & - & - & - & - & 2.0 & - & - \\
$\mathrm{C}_{12: 0}$ ALDE & - & 1.8 & - & - & - & - & - \\
$\mathrm{C}_{14: 0} 3-\mathrm{OH}$ & - & - & $\mathrm{NA}$ & $\mathrm{NA}$ & 1.5 & $\mathrm{NA}$ & - \\
$\mathrm{C}_{18: 1} \omega 7 c$ & 80.4 & 78.9 & 80.2 & 84.0 & 84.3 & 80.3 & 83.5 \\
$\mathrm{C}_{18: 0}$ & 6.1 & 4.5 & 3.6 & 5.2 & 7.8 & 2.6 & 2.5 \\
$\mathrm{C}_{18: 0} 3-\mathrm{OH}$ & - & 1.1 & - & - & - & - & - \\
$\mathrm{C}_{19: 0}$ cyclo $\omega 8 c$ & 2.6 & - & - & - & - & - & - \\
$11-$ Methyl C $18: 1 \omega 7 c$ & - & 5.8 & - & - & - & - & 1.5 \\
Summed feature $2 *$ & - & - & 2.9 & 2.1 & - & 3.0 & - \\
\hline
\end{tabular}

*Summed feature 2 comprised $\mathrm{C}_{14: 0} 3-\mathrm{OH}$ and/or $\mathrm{C}_{16: 1}$ iso I. hydrolase, $\beta$-galactosidase, $\alpha$-glucosidase, $\beta$-glucosidase and $N$-acetyl- $\beta$-glucosaminidase; no activity is observed for lipase (C14), $\alpha$-chymotrypsin, $\alpha$-galactosidase, $\beta$ glucuronidase, $\alpha$-mannosidase or $\alpha$-fucosidase. The following substrates are utilized as sole carbon or nitrogen and energy sources with the Biolog GN2 system: $\alpha$-cyclodextrin, dextrin, glycogen, $\mathrm{N}$-acetyl-D-galactosamine, adonitol, Larabinose, D-arabitol, L-fucose, D-fructose, D-galactose, gentiobiose, $\alpha$-D-glucose, $\alpha$-D-lactose, D-mannose, melibiose, D-psicose, D-sorbitol, sucrose, turanose, xylitol, methyl pyruvate, monomethyl succinate, acetic acid, cisaconitic acid, citric acid, formic acid, D-galacturonic acid, D-gluconic acid, D-glucosaminic acid, D-glucuronic acid, $\alpha$ hydroxybutyric acid, $\beta$-hydroxyphenylacetic acid, $\gamma$-hydroxybutyric acid, $\alpha$-ketobutyric acid, $\alpha$-ketoglutaric acid, DLlactic acid, quinic acid, D-saccharic acid, succinic acid, bromosuccinic acid, succinamic acid, glucuronamide, Lalaninamide, DL-alanine, L-alanyl glycine, L-asparagine, Laspartic acid, L-glutamic acid, glycyl L-aspartic acid, glycyl L-glutamic acid, L-histidine, hydroxy-L-proline, L-leucine, L-ornithine, L-proline, DL-serine, L-threonine, DL-carnitine, $\gamma$-aminobutyric acid, urocanic acid, inosine, uridine, thymidine, phenylethylamine, putrescine, 2 -aminoethanol, 2,3-butanediol, glycerol, DL- $\alpha$-glycerol phosphate, glucose 1-phosphate and glucose 6-phosphate. The following substrates are not utilized: Tweens 40 and $80, N$-acetyl-Dglucosamine, cellobiose, i-erythritol, myo-inositol, lactose, lactulose, maltose, D-mannitol, methyl $\beta$-D-glucoside, raffinose, L-rhamnose, trehalose, D-galactonic acid lactone, $p$-hydroxybutyric acid, $\alpha$-ketovaleric acid, malonic acid, propionic acid, sebacic acid, L-phenylalanine, L-pyroglutamic acid and phenylethylamine. Ubiquinone Q-10 is the predominant isoprenoid quinone. The major fatty acid is $\mathrm{C}_{18: 1} \omega 7 \mathrm{c}$. The $\mathrm{G}+\mathrm{C}$ content of the type strain is $60.3 \mathrm{~mol} \%$.

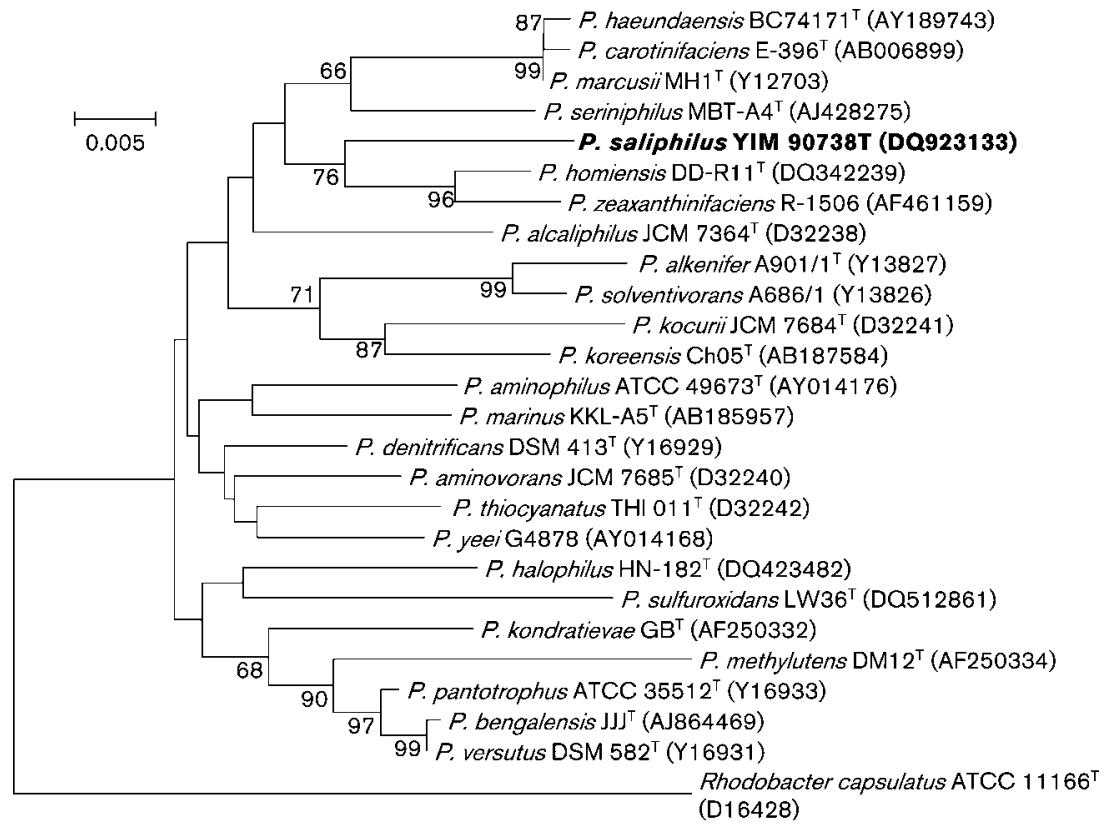

Fig. 1. Neighbour-joining phylogenetic tree based on 16S rRNA gene sequences showing the position of strain $\mathrm{YIM} 90738^{\top}$ among species of the genus Paracoccus. Numbers at branch points are bootstrap values (percentages based on 1000 resamplings; only values above $50 \%$ are shown). The sequence of Rhodobacter capsulatus ATCC $11166^{\top}$ was used as the outgroup. Bar, $0.5 \%$ sequence divergence. 
The type strain, YIM $90738^{\mathrm{T}}$ (=CCTCC AB $206074^{\mathrm{T}}$ $=$ KCTC $22163^{\mathrm{T}}$ ), was isolated from a salt lake in Xinjiang Province, north-west China.

\section{Acknowledgements}

This research was supported by the National Basic Research Program of China (no. 2004CB719601), the Key Project of the Chinese Ministry of Education (no. 206139), the National Natural Science Foundation of China (nos 30600001, 30860002 and 30870005), the Open Project Program of the Extremophiles Lab of Xinjiang (no. XJYS0203-2005-01) and the Youth Technological Innovation Foundation of Xinjiang Academy of Agricultural Science (no. 2007Q07). W.-J. L. was supported by the Program for New Century Excellent Talents in University.

\section{References}

Berry, A., Janssens, D., Hümbelin, M., Jore, J. P. M., Hoste, B., Cleenwerck, I., Vancanneyt, M., Bretzek, W., Mayer, A. F. \& other authors (2003). Paracoccus zeaxanthinifaciens sp. nov., a zeaxanthinproducing bacterium. Int J Syst Evol Microbiol 53, 231-238.

Cerny, G. (1978). Studies on aminopeptidase for the distinction of Gram-negative from Gram-positive bacteria. Eur J Appl Microbiol Biotechnol 5, 113-122.

Cowan, S. T. \& Steel, K. J. (1965). Manual for the Identification of Medical Bacteria. London: Cambridge University Press.

Davis, D. H., Doudoroff, M., Stanier, R. Y. \& Mandel, M. (1969). Proposal to reject the genus Hydrogenomonas: taxonomic implications. Int J Syst Bacteriol 19, 375-390.

De Ley, J. \& Tijtgat, R. (1970). Evaluation of membrane filter methods for DNA-DNA hybridization. Antonie van Leeuwenhoek 36, 461-474.

Doronina, N. V., Trotsenko, Y. A., Kuznetzov, B. B. \& Tourova, T. P. (2002). Emended description of Paracoccus kondratievae. Int J Syst Evol Microbiol 52, 679-682.

Ezaki, T., Hashimoto, Y. \& Yabuuchi, E. (1989). Fluorometric deoxyribonucleic acid-deoxyribonucleic acid hybridization in microdilution wells as an alternative to membrane filter hybridization in which radioisotopes are used to determine genetic relatedness among bacterial strains. Int J Syst Bacteriol 39, 224-229.

Felsenstein, J. (1981). Evolutionary trees from DNA sequences: a maximum likelihood approach. J Mol Evol 17, 368-376.

Felsenstein, J. (1985). Confidence limits on phylogenies: an approach using the bootstrap. Evolution 39, 783-791.

Fitch, W. M. (1971). Toward defining the course of evolution: minimum change for a specific tree topology. Syst Zool 20, 406-416.

Harker, M., Hirschberg, J. \& Oren, A. (1998). Paracoccus marcusii sp. nov., an orange Gram-negative coccus. Int J Syst Bacteriol 48, 543-548.

Katayama, Y., Hiraishi, A. \& Kuraishi, H. (1995). Paracoccus thiocyanatus sp. nov., a new species of thiocyanate-utilizing facultative chemolithotroph, and transfer of Thiobacillus versutus to the genus Paracoccus as Paracoccus versutus comb. nov. with emendation of the genus. Microbiology 141, 1469-1477.

Khan, S. T., Takaichi, S. \& Harayama, S. (2008). Paracoccus marinus sp. nov., an adonixanthin diglucoside-producing bacterium isolated from coastal seawater in Tokyo Bay. Int J Syst Evol Microbiol 58, 383-386.

Kim, B. Y., Weon, H. Y., Yoo, S. H., Kwon, S. W., Cho, Y. H., Stackebrandt, E. \& Go, S. J. (2006). Paracoccus homiensis sp. nov., isolated from a sea-sand sample. Int J Syst Evol Microbiol 56, 2387-2390.

Kimura, M. (1980). A simple method for estimating evolutionary rates of base substitutions through comparative studies of nucleotide sequence. J Mol Evol 16, 111-120.
Komagata, K. \& Suzuki, K. (1987). Lipid and cell-wall analysis in bacterial systematics. Methods Microbiol 19, 161-207.

Kumar, S., Tamura, K. \& Nei, M. (2004). MEGA3: integrated software for molecular evolutionary genetics analysis and sequence alignment. Brief Bioinform 5, 150-163.

Kushner, D. J. \& Kamekura, M. (1988). Physiology of halophilic eubacteria. In Halophilic Bacteria, vol. I, pp. 109-140. Edited by F. Rodríguez-Valera. Boca Raton, FL: CRC Press.

Lányí, B. (1987). Classical and rapid identification methods for medically important bacteria. Methods Microbiol 19, 1-67.

Lee, J. H., Kim, Y. S., Choi, T.-J., Lee, W. J. \& Kim, Y. T. (2004). Paracoccus haeundaensis sp. nov., a Gram-negative, halophilic, astaxanthin-producing bacterium. Int J Syst Evol Microbiol 54, 1699-1702.

Leifson, E. (1960). Atlas of Bacterial Flagellation. London: Academic Press.

Li, W. J., Xu, P., Schumann, P., Zhang, Y. Q., Pukall, R., Xu, L. H., Stackebrandt, E. \& Jiang, C. L. (2007). Georgenia ruanii sp. nov., a novel actinobacterium isolated from forest soil in Yunnan (China) and emended description of the genus Georgenia. Int J Syst Evol Microbiol 57, 1424-1428.

Liu, X.-Y., Wang, B.-J., Jiang, C.-Y. \& Liu, S.-J. (2006). Paracoccus sulfuroxidans sp. nov., a sulfur oxidizer from activated sludge. Int $J$ Syst Evol Microbiol 56, 2693-2695.

Liu, Z.-P., Wang, B.-J., Liu, X.-Y., Dai, X., Liu, Y.-H. \& Liu, S.-J. (2008). Paracoccus halophilus sp. nov., isolated from marine sediment of the South China Sea, China, and emended description of genus Paracoccus Davis 1969. Int J Syst Evol Microbiol 58, 257-261.

Ludwig, W., Mittenhuber, G. \& Friedrich, C. G. (1993). Transfer of Thiosphaera pantotropha to Paracoccus denitrificans. Int J Syst Bacteriol 43, 363-367.

Mesbah, M., Premachandran, U. \& Whitman, W. B. (1989). Precise measurement of the $\mathrm{G}+\mathrm{C}$ content of deoxyribonucleic acid by highperformance liquid chromatography. Int J Syst Bacteriol 39, 159-167.

Pukall, R., Laroche, M., Kroppenstedt, R. M., Schumann, P., Stackebrandt, E. \& Ulber, R. (2003). Paracoccus seriniphilus sp. nov., an L-serine-dehydratase-producing coccus isolated from the marine bryozoan Bugula plumosa. Int J Syst Evol Microbiol 53, 443-447.

Saitou, N. \& Nei, M. (1987). The neighbor-joining method: a new method for reconstructing phylogenetic trees. Mol Biol Evol 4, 406-425.

Sasser, M. (1990). Identification of bacteria by gas chromatography of cellular fatty acids. USFCC Newsl 20, 16.

Stackebrandt, E. \& Goebel, B. M. (1994). Taxonomic note: a place for DNA-DNA reassociation and $16 \mathrm{~S}$ rRNA sequence analysis in the present species definition in bacteriology. Int J Syst Bacteriol 44, 846-849.

Thompson, J. D., Gibson, T. J., Plewniak, F., Jeanmougin, F. \& Higgins, D. G. (1997). The CLUSTAL_X windows interface: flexible strategies for multiple sequence alignment aided by quality analysis tools. Nucleic Acids Res 25, 4876-4882.

Tsubokura, A., Yoneda, H. \& Mizuta, H. (1999). Paracoccus carotinifaciens sp. nov., a new aerobic Gram-negative astaxanthinproducing bacterium. Int J Syst Bacteriol 49, 277-282.

Wayne, L. G., Brenner, D. J., Colwell, R. R., Grimont, P. A. D., Kandler, O., Krichevsky, M. I., Moore, L. H., Moore, W. E. C., Murray, R. G. E. \& other authors (1987). International Committee on Systematic Bacteriology. Report of the ad hoc committee on reconciliation of approaches to bacterial systematics. Int J Syst Bacteriol 37, 463-464.

Xu, P., Li, W.-J., Tang, S.-K., Zhang, Y.-O., Chen, G.-Z., Chen, H.-H., Xu, L.-H. \& Jiang, C.-L. (2005). Naxibacter alkalitolerans gen. nov., sp. nov., a novel member of the family 'Oxalobacteraceae' isolated from China. Int J Syst Evol Microbiol 55, 1149-1153. 